\title{
Extensive temporal transcriptome and microRNA analyses identify molecular mechanisms underlying mitochondrial dysfunction induced by multi-walled carbon nanotubes in human lung cells
}

Citation for published version (APA):

Nymark, P., Wijshoff, P., Cavill, R., van Herwijnen, M., Coonen, M. L. J., Claessen, S., Catalan, J., Norppa, H., Kleinjans, J., \& Briede, J. J. (2015). Extensive temporal transcriptome and microRNA analyses identify molecular mechanisms underlying mitochondrial dysfunction induced by multi-walled carbon nanotubes in human lung cells. Nanotoxicology, 9(5), 624-635.

https://doi.org/10.3109/17435390.2015.1017022

Document status and date:

Published: 01/01/2015

DOI:

10.3109/17435390.2015.1017022

Document Version:

Publisher's PDF, also known as Version of record

Document license:

Taverne

Please check the document version of this publication:

- A submitted manuscript is the version of the article upon submission and before peer-review. There can be important differences between the submitted version and the official published version of record. People interested in the research are advised to contact the author for the final version of the publication, or visit the DOI to the publisher's website.

- The final author version and the galley proof are versions of the publication after peer review.

- The final published version features the final layout of the paper including the volume, issue and page numbers.

Link to publication

\footnotetext{
General rights rights.

- You may freely distribute the URL identifying the publication in the public portal. please follow below link for the End User Agreement:

www.umlib.nl/taverne-license

Take down policy

If you believe that this document breaches copyright please contact us at:

repository@maastrichtuniversity.nl

providing details and we will investigate your claim.
}

Copyright and moral rights for the publications made accessible in the public portal are retained by the authors and/or other copyright owners and it is a condition of accessing publications that users recognise and abide by the legal requirements associated with these

- Users may download and print one copy of any publication from the public portal for the purpose of private study or research.

- You may not further distribute the material or use it for any profit-making activity or commercial gain

If the publication is distributed under the terms of Article 25fa of the Dutch Copyright Act, indicated by the "Taverne" license above,

Download date: 26 Apr. 2023 


\section{Nanotoxicology Nanotoxicology}

\section{Extensive temporal transcriptome and microRNA analyses identify molecular mechanisms underlying mitochondrial dysfunction induced by multi-walled carbon nanotubes in human lung cells}

Penny Nymark, Peter Wijshoff, Rachel Cavill, Marcel van Herwijnen, Maarten L. J. Coonen, Sandra Claessen, Julia Catalán, Hannu Norppa, Jos C. S. Kleinjans \& Jacob J. Briedé

To cite this article: Penny Nymark, Peter Wijshoff, Rachel Cavill, Marcel van Herwijnen, Maarten L. J. Coonen, Sandra Claessen, Julia Catalán, Hannu Norppa, Jos C. S. Kleinjans \& Jacob J. Briedé (2015) Extensive temporal transcriptome and microRNA analyses identify molecular mechanisms underlying mitochondrial dysfunction induced by multi-walled carbon nanotubes in human lung cells, Nanotoxicology, 9:5, 624-635, DOI: 10.3109/17435390.2015.1017022

To link to this article: https://doi.org/10.3109/17435390.2015.1017022

$+\quad$ View supplementary material $\widetilde{T}$

Submit your article to this journal $₫$
Published online: 01 Apr 2015. 


\title{
Extensive temporal transcriptome and microRNA analyses identify molecular mechanisms underlying mitochondrial dysfunction induced by multi-walled carbon nanotubes in human lung cells
}

\author{
Penny Nymark ${ }^{1,2}$, Peter Wijshoff ${ }^{1}$, Rachel Cavill ${ }^{1}$, Marcel van Herwijnen ${ }^{1}$, Maarten L. J. Coonen ${ }^{1}$, Sandra Claessen ${ }^{1}$, \\ Julia Catalán ${ }^{3,4}$, Hannu Norppa ${ }^{3}$, Jos C. S. Kleinjans ${ }^{1}$, and Jacob J. Briedé ${ }^{1}$ \\ ${ }^{1}$ Department of Toxicogenomics, Maastricht University, Maastricht, The Netherlands, ${ }^{2}$ Institute of Environmental Medicine, Karolinska Institutet, \\ Stockholm, Sweden, ${ }^{3}$ Nanosafety Research Center and Systems Toxicology, Health and Work Ability, Finnish Institute of Occupational Health, \\ Helsinki, Finland, and ${ }^{4}$ Department of Anatomy, Embryology and Genetics, University of Zaragoza, Zaragoza, Spain
}

\begin{abstract}
Understanding toxicity pathways of engineered nanomaterials (ENM) has recently been brought forward as a key step in twenty-first century ENM risk assessment. Molecular mechanisms linked to phenotypic end points is a step towards the development of toxicity tests based on key events, which may allow for grouping of ENM according to their modes of action. This study identified molecular mechanisms underlying mitochondrial dysfunction in human bronchial epithelial BEAS 2B cells following exposure to one of the most studied multiwalled carbon nanotubes (Mitsui MWCNT-7). Asbestos was used as a positive control and a non-carcinogenic glass wool material was included as a negative fibre control. Decreased mitochondrial membrane potential (MMP $\downarrow$ ) was observed for MWCNTs at a biologically relevant dose $\left(0.25 \mu \mathrm{g} / \mathrm{cm}^{2}\right)$ and for asbestos at $2 \mu \mathrm{g} / \mathrm{cm}^{2}$, but not for glass wool. Extensive temporal transcriptomic and microRNA expression analyses identified a 330-gene signature (including 26 genes with known mitochondrial function) related to MWCNT- and asbestos-induced MMP $\downarrow$. Forty-nine of the MMP $\downarrow$-associated genes showed highly similar expression patterns over time (six time points) and the majority was found to be regulated by two transcription factors strongly involved in mitochondrial homeostasis, APP and NRF1. In addition, four miRNAs were correlated with MMP $\downarrow$ and one of them, miR-1275, was found to negatively correlate with a large part of the MMP $\downarrow$-associated genes. Cellular processes such as gluconeogenesis, mitochondrial LC-fatty acid $\beta$-oxidation and spindle microtubule function were enriched among the MMP $\downarrow$-associated genes and miRNAs. These results are expected to be useful in the identification of key events in ENM-related toxicity pathways for the development of molecular screening techniques.
\end{abstract}

\section{Keywords}

Asbestos, gene expression, glass wool, microRNA, mitochondrial membrane potential, multi-walled carbon nanotubes

\section{History}

Received 25 November 2014

Revised 3 February 2015

Accepted 5 February 2015

Published online 1 April 2015

\section{Introduction}

Multi-walled carbon nanotubes (MWCNTs) are among the most commercialised engineered nanomaterials (ENMs) used in a wide variety of consumer products (De Volder et al., 2013). However, while the market for MWCNTs is growing with a steady rate and future carbon nanotube-based technology is expected to have a tremendous impact on the development of several new technologies (De Volder et al., 2013), certain MWCNTs appear to possess toxic potency, based on comparison with a well-known human carcinogen, asbestos, both in vitro and in vivo (Poland et al., 2008; Sargent et al., 2014; Siegrist et al., 2014; SnyderTalkington et al., 2013; Takagi et al., 2008, 2012).

One of the most frequently studied types of MWCNTs Mitsui MWCNT-7, which in terms of morphology and toxicology seems to be highly similar to asbestos, was recently classified as a

Correspondence: Dr. Penny Nymark, Institute of Environmental Medicine, Karolinska Institutet, Stockholm, Sweden. E-mail: penny.nymark@ki.se possible human carcinogen (Grosse et al., 2014; IARC Group 2B). MWCNT-7 has shown both dose-dependent induction of mesothelioma and promotion of lung adenocarcinoma (AC) in mice (Sargent et al., 2014; Takagi et al., 2012). In vitro studies in human airway epithelial cells have indicated that MWCNT-7 can induce changes related to neoplastic transformation, such as increased cell proliferation, cell migration and angiogenesis in similar quantities as crocidolite asbestos (Wang et al., 2014). Numerous studies have addressed immuno-, geno- and cytotoxicity in various types of target cells using different forms of MWCNTs (Lindberg et al., 2013; Palomäki et al., 2011; Siegrist et al., 2014). Nevertheless, knowledge about the mechanisms underlying the adverse health effects of these materials, especially at a subcellular level, is still too scarce and discrepant to allow for efficient and accurate risk assessment. A further complication is the large variety of MWCNTs with different physical properties. All forms of MWCNTs are not expected to be harmful and mechanistic knowledge may help in distinguishing between the hazardous and non-hazardous varieties (Toyokuni, 2013).

One of the main cellular processes that has been shown to be altered by asbestos is mitochondrial function and activity 
(Huang et al., 2012). Mitochondria play a central role in regulating several key cellular functions, including apoptosis, glucose metabolism, maintenance of oxidant-antioxidant balance and cell cycle regulation, which is why their dysfunctions are related to a wide variety of human diseases, such as Alzheimer's and cardiovascular disease, as well as fibrosis and carcinogenesis, the two primary pathogenic effects of asbestos in humans (Antico Arciuch et al., 2012; Liu et al., 2013; Liu \& Kamp, 2011; Nymark et al., 2008). Asbestos-induced mitochondrial dysfunction is thought to be related to apoptosis or to apoptotic bypass and an increased formation of reactive oxygen species (ROS), leading to a feedback loop between oxidative stress-activated gene expression and uncontrolled ROS formation (Huang et al., 2012; Nymark et al., 2008; Panduri et al., 2004). Asbestos has been shown to induce a decrease in mitochondrial membrane potential (MMP $\downarrow)$ and an increase in mitochondria-mediated apoptosis in a dose- and time-dependent manner in the lung cancer cell line A549 (Panduri et al., 2003). Also, MWCNTs have been shown to cause mitochondrial dysfunction through MMP $\downarrow$, as well as apoptosis and intracellular ROS formation in a variety of cell types, including A549 (Pulskamp et al., 2007; Wang et al., 2012). However, low biologically relevant doses have not frequently been employed in vitro, and the molecular mechanisms underlying these effects have not yet been elucidated.

In this study, we have characterised gene and microRNA (miRNA) expression changes associated with mitochondrial dysfunction in human bronchial epithelial cells after exposure to low biologically relevant doses $\left(0.25\right.$ and $\left.2 \mu \mathrm{g} / \mathrm{cm}^{2}\right)$ of MWCNT7. Similar low doses of MWCNTs have been shown to induce fibrotic changes both in vivo and in vitro (see Supplementary material for dose calculations) (Mishra et al., 2012; Poulsen et al., 2013; Ryman-Rasmussen et al., 2009). We also theorised that the use of both positive and negative well-known and well-studied fibre controls would facilitate identification of biologically relevant molecular mechanisms in vitro. Asbestos has previously been used as a positive control in some studies (Lindberg et al., 2013; Palomäki et al., 2011; Siegrist et al., 2014); however, negative control fibres are not frequently reported in these types of studies. Certain types of glass wool, such as the man-made vitreous fibre 10 (MMVF10), a widely used insulation glass fibre, are thought to be non-carcinogenic to humans (IARC, 2002) and could serve as negative fibre controls. MMVF10 has been shown to be phagocytised by macrophages both in vivo and in vitro, as well as to be trapped in the cleavage furrow of dividing mesothelial cells (Geiser et al., 2003; Jensen \& Watson, 1999; Tran et al., 1996). Thus, indicating that, although MMVF10 fibres are slightly larger than the MWCNT and asbestos fibres, they can be internalised by cells. MMVF10 has also been shown to cause frustrated phagocytosis, similar to both MWCNTs and asbestos (Dörger et al., 2000). Nevertheless, in contrast to asbestos, no increase in tumour formation has been observed following chronic inhalation exposure to MMVF10 in several different animal models (Hesterberg et al., 1993, 1997; Mcconnell et al., 1999). Furthermore, no mutagenic effects and no increase in oxidative damage was seen following intra-tracheal instillation (Topinka et al., 2006). MMVF10 also showed low free-radical activity during exposure in vitro (Gilmour et al., 1997; Nymark et al., 2014) and approximately $0.25 \mu \mathrm{g} / \mathrm{cm}^{2}$ MMVF10 induced only weak inflammatory reactions in rat lungs following intra-tracheal instillation (see Supplementary material for dose calculations) (Topinka et al., 2006). Thus, we hypothesised that MMVF10 does not induce mitochondrial oxidative stress, and consequently, may act as a negative fibre control, together with the positive control asbestos, in our study design.

Finally, we used the immortalised bronchial epithelial cell line, BEAS 2B, which is grown in serum-free medium, p53 wild-type, able to enter squamous differentiation, has a normal antioxidant capacity, and has been reported to be highly homologous to primary lung cell lines and to human lung tissue in terms of gene expression pattern (Courcot et al., 2012; Garcia-Canton et al., 2013; Kinnula et al., 1994). To be noted, this cell line is widely used in asbestos and nanotoxicological research and is capable of MWCNT endocytosis, while undergoing cell division (Haniu et al., 2011; Nymark et al., 2007).

\section{Materials and methods}

\section{Test materials and their characterisations}

Commercially available MWCNTs (MWCNT-XNRI-7) were obtained from Mitsui \& Co., Ltd., Tokyo, Japan (Lot\# 05072001K28), standard reference crocidolite asbestos was purchased from UICC (Union for International Cancer Control, Geneva Switzerland), and MMVF10 glass wool was kindly provided by Dr David Brown (School of Life Sciences of the Heriot-Watt University, Edinburgh, United Kingdom). The materials have previously been characterised (Nymark et al., 2014) and specifics can be reviewed in Table 1 .

\section{Preparation of exposure dispersions}

Material dispersions were prepared in glass tubes as stock dispersions of $1 \mathrm{mg} / \mathrm{ml}$ in cell growth medium (BEGM, Clonetics, Walkerwille, MD) with $0.6 \mathrm{mg} / \mathrm{ml}$ of bovine serum albumin (BSA; Sigma-Aldrich, Steinheim, Germany) and sonicated in a bath sonicator (Branson $2200,40 \mathrm{kHz}, 20 \mathrm{~min}, 37^{\circ} \mathrm{C}$ ). The freshly prepared and sonicated stock dispersions were further serially diluted to obtain the final dispersions of $0.25,2$ and $10 \mu \mathrm{g} /$ $\mathrm{cm}^{2}$ (corresponding to 2,16 and $80 \mu \mathrm{g} / \mathrm{ml}$ ), sonicated again $\left(20 \mathrm{~min}, 37^{\circ} \mathrm{C}\right)$ and directly applied onto the cells.

Characterisation in terms of size, agglomeration and sedimentation rate of the materials in exposure medium has previously been described for the materials (Nymark et al., 2014). Briefly, all three materials showed similar rapid sedimentation profiles in cell culture media, indicating that the cells were in contact with the agents already at early time points of the experiment (Table 1).

\section{Cell culture}

Transformed human bronchial epithelial BEAS 2B cells, exhibiting an epithelial phenotype (Reddel et al., 1988), were obtained from the American Type Culture Collection through LGC Promochem AB (Borås, Sweden). The BEAS 2B cells were grown (passages 49-50) in serum-free BEGM medium at $37^{\circ} \mathrm{C}$ in a humidified atmosphere of $5 \% \mathrm{CO}_{2}$.

Cytotoxicity (estimated $\mathrm{IC}_{20}$ values) for the exposure materials in BEAS 2B cells can be reviewed in Table 1 (based on Nymark et al., 2014).

\section{Mitochondrial membrane potential (MMP)}

Cells were exposed to $0.25,2$ and $10 \mu \mathrm{g} / \mathrm{cm}^{2}$ MWCNTs, asbestos and glass wool (referred to as MWCNT025, MWCNT2, MWCNT10, ASB025, ASB2, ASB10, GW025, GW2 and GW10 in the following) for $24 \mathrm{~h}$, and the persistence of the effects was tested for the two lower doses $\left(0.25\right.$ and $\left.2 \mu \mathrm{g} / \mathrm{cm}^{2}\right)$ at $48 \mathrm{~h}$. Three independent experiments were performed to obtain a total of three biological replicates for each experimental condition.

Changes in MMP were detected using flow cytometry

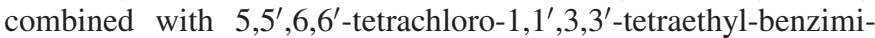
dazolcarbocyanine iodide (JC-1) staining (BD ${ }^{\mathrm{TM}}$ MitoScreen, BD Biosciences, San Jose, CA). Carbonyl cyanide 
3-chlorophenylhydrazone (CCCP), a mitochondrial uncoupler, was used at $100 \mu \mathrm{M}$ for $5 \mathrm{~min}$ as an assay-specific positive control (based on: http://www.bdj.co.jp/flow/articles/hkdqj200000i4jvpatt/BD_Accuri_Detect_Apoptosis_TechBulletin.pdf).

The exposed cells were trypsinised for $15 \mathrm{~min}$, and $10 \%$ fetal calf serum (FCS, Gibco BRL, Breda, the Netherlands) in Hank's Balanced Salt Solution (HBSS; Gibco; Life Technologies Europe BV; Bleiswijk, the Netherlands) was added. The cells were washed with HBSS and stained with JC-1 according to the instruction manual (https://www.bdbiosciences.com/external files/pm/doc/manuals/live/web_enabled/02-8100055-551302Br.pdf). The stained cells were filtered through a $50-\mu \mathrm{m}$ nylon mesh and 10000 cells/replicate (i.e. 30000 cells/exposure condition) were analysed by flow cytometry (Becton Dickinson FACSort with 488-nm laser).

Flowing software 2.5.0 (http://www.flowingsoftware.com/, Perttu Terho, University of Turku and Åbo Akademi University, Finland) was used to analyse the results. Unexposed cells were used to set the R1 gate (red fluorescence: $590 \mathrm{~nm}$ - indicating healthy mitochondria) and CCCP-exposed cells to set the R2 gate (green fluorescence: $527 \mathrm{~nm}$ - indicating MMP $\downarrow$ ). The ratio of the R1 and R2 gates was calculated for each exposure condition and compared to that of the corresponding control, to determine the percentage of cells with unchanged MMP. Statistical analysis (exposed versus control) was performed using an unpaired two-tailed $t$-test and $p<0.05$ was considered significant.

Since effects on the MMP were seen already at the two lower doses (see Results section), these were used for all other experiments.

\section{Mitochondrial radical formation}

Mitochondria were isolated from cells exposed to 0.25 and $2 \mu \mathrm{g} /$ $\mathrm{cm}^{2}$ MWCNTs, asbestos and glass wool for $24 \mathrm{~h}$, as described previously (Nabben et al., 2011). Two independent experiments were performed to obtain two replicates for each exposure condition. The mitochondria were diluted (ultimate protein concentration $0.05 \mathrm{mg} / \mathrm{ml}$ ) in MiB01 (17.115 g $100 \mathrm{mM}$ sucrose; $2.295 \mathrm{~g} 20 \mathrm{mM}$ TES; $1.864 \mathrm{~g} 50 \mathrm{mM}$ KCL; $0.146 \mathrm{~g} 1 \mathrm{mM}$ EDTA; $1.0 \mathrm{~g} 0.2 \%$ FA-free BSA; $\mathrm{KOH}$ was used to set $\mathrm{pH} 7.40$ ), incubated for $5 \mathrm{~min}$ at $37^{\circ} \mathrm{C}$, and reactivated with $800 \mathrm{mM}$ malate, $2 \mathrm{M}$ glutamate and $1 \mathrm{M}$ succinate for $20 \mathrm{~min}$ at $37^{\circ} \mathrm{C}$. ESR spectroscopy in combination with the spin probe 1-hydroxy-3carboxy-2,2,5,5-tetramethylpyrrolidine (CPH; $40 \mathrm{mM}$ was added together with the reactivation substrates) was used to determine mitochondrial radical formation as described earlier (Piskernik et al., 2008).

To ensure that superoxide radicals were indeed being detected, two additional analyses were performed using $1 \mathrm{U} / \mu \mathrm{l}$, superoxide dismutase (SOD; Sigma-Aldrich Chemie B.V. Nederland). Radical formation was measured in triplicate for each sample on a Bruker EMX 1273 (Bruker; Rheinstetten, Germany) equipped with an ER 4119HS high-sensitivity resonator and $12 \mathrm{~kW}$ power supply operating at $\mathrm{X}$ band frequencies. The modulation frequency of the spectrometer was $100 \mathrm{kHz}$. Instrumental conditions for the recorded spectra were as follows: magnetic field, $3490 \mathrm{G}$; scan range, $100 \mathrm{G}$; modulation amplitude, $1 \mathrm{G}$; receiver gain, $1 \times 10^{5}$; microwave frequency, $9.85 \mathrm{GHz}$; power, $50 \mathrm{~mW}$; time constant, $40.96 \mathrm{~ms}$; scan time, $20.97 \mathrm{~s}$; number of scans, 10.

The CPH signal was analysed by using the WIN-EPR spectrum qualification programme (version 2.11, Bruker, Rheinstetten, Germany). Quantification of the spectra was performed as described in previous studies (Hebels et al., 2010) by means of peak surface measurements through double integration of the 
$\mathrm{CPH}$ signal. Statistical analysis was performed using an unpaired two-tailed $t$-test, where $p<0.05$ was considered significant.

\section{Total RNA extraction and microarray experiments}

Cells were exposed to 0.25 and $2 \mu \mathrm{g} / \mathrm{cm}^{2}$ MWCNTs, asbestos and glass wool for $1,4,6,12,24$ and $48 \mathrm{~h}$. Three independent experiments were performed to obtain a total of three replicates for each exposure condition.

Total RNA was extracted using $0.5 \mathrm{ml}$ TRIZOL (Life Technologies, Carlsbad, CA) according to the manufacturer's instructions and purified using miRNeasy ${ }^{\circledR}$ Mini Kits (kit 217004, Qiagen, miRNeasy Mini Handbook). Sample preparation, hybridisation, washing, staining and scanning of Affymetrix Human GeneChip HT HG-U133 Plus 24-Array Plates and Agilent Human miRNA Microarrays $(8 \times 60 \mathrm{~K})$ were conducted according to the manufacturers' standard manuals (Affymetrix GeneChip $3^{\prime}$ IVT Express Kit User Manual, the GeneTitan Manual and the Agilent miRNA Microarray System Manual) as previously described (Deferme et al., 2013; Van Den Hof et al., 2014). For Affymetrix arrays, quality control was performed using the ArrayAnalysis.org (www.arrayanalysis.org) web service (Eijssen et al., 2013). For Agilent, an in-house pipeline developed in R statistical language was used (R Core Team, 2014). Foreground and background intensity, spot saturation, spot mean-median ratio and level above background were evaluated. All arrays included in the study were of high quality. Hybridisation controls were called "present" on all arrays and yielded the expected increases in intensities. The data in this publication are accessible in the Gene Expression Omnibus (GEO) database (http://www.ncbi.nlm.nih.gov/geo/) through the accession number GSE63580.

\section{Annotation, normalisation and filtering of microarray data}

The gene expression data were RMA normalised using ArrayAnalysis.org (Eijssen et al., 2013), re-annotated to EntrezGeneIDs using BrainArray's custom CDF files (Dai et al., 2005) and filtered on expression level ( $\log _{2}$ intensity $>6$ in at least one sample). Pre-processing of the miRNA data was performed by the R/Bioconductor package AgiMicroRNA (Lopez-Romero, 2011). Total gene signals were quantile-normalised, $\log _{2}$ transformed and filtered on is GeneDetected flag according to the script. Only miRNAs expressed in at least two samples were included in the analysis.

\section{Differentially expressed genes and microRNAs}

Differentially expressed genes (DEGs) were determined with limma (linear models for microarray data analysis) in $\mathrm{R}$ (version 3.0.2 for 64-bit Windows) (R Core Team, 2014; Smyth et al., 2005) using paired analysis, $\log _{2}$-fold change $>0.25$ and $p<0.05$.

Differentially expressed miRNAs (DEmiRs) were identified by paired empirical Bayes test in Chipster (v. 12.1.0; http:// chipster.csc.fi/). miRNAs with $p<0.05$ and a $\log _{2}$-fold change of 0.2 were considered statistically significant.

A liberal approach, using un-adjusted $p$ values and low-fold changes, was applied to both the mRNA and the miRNA data, to be able to identify low-level changes considering the low doses that were used. This enabled analysis of whole gene sets that together significantly affected a biological process or pathway. Furthermore, negative correlations between miRNA data and target genes enhanced the relative significance of low-level changes detected in each data set separately.

The web tool VENNY (http://bioinfogp.cnb.csic.es/tools/ venny/) was used to compare lists of genes/miRNAs from the different exposures (Oliveros, 2007).

\section{Nuclear transcribed mitochondria-related genes and microRNAs}

A list of nuclear transcribed mitochondria-related genes was established based on the mitoP2 and DAVID databases (Huang et al., 2008; Prokisch et al., 2006). Combined, 1243 unique mitochondria-related genes were identified and of those 1161 were present on the Affymetrix arrays. In addition, a list of 67 miRNAs related to mitochondrial function was established based on literature (Bienertova-Vasku et al., 2013; Tomasetti et al., 2014). Mitochondria-related DEGs (mtDEGs) and DEmiRs (mitomiRs) were identified in the data sets using these lists.

\section{Bioinformatics analysis}

\section{PCA analysis}

Principal component analysis (PCA) was performed using a custom-made script in R on the MMP-associated genes (see the Results section) to assess differences in exposure effect. Principal components of samples belonging to the same treatment group were pooled, and Euclidean distances were calculated to get a quantitative insight in exposure similarity. Variation explained by the first three principal components was visualised in threedimensional PCA plots.

\section{Gene ontology, pathway and gene network analysis}

Chipster (v. 2.12; http://chipster.csc.fi/) was used to perform hyper-geometric tests on the enrichment of gene ontology (GO) terms, including biological process, molecular function and cellular component, in the identified DEG lists of interest. Default settings were applied as follows; $p<0.05$, minimum number of genes in GO term tested: 5, and "conditional testing" so that significant genes tested in a child term were removed before testing the parent term.

ConsensusPathDB (CPDB version 29, http://cpdb.mplgen. mpg.de) (Kamburov et al., 2013) was used to identify relevant pathways (WikiPathways, Reactome, BioCarta, KEGG and GO terms on the 4th level) enriched in the shorter DEG lists of interest. The complete mitochondrial gene list (1161 genes) was used as a background list when searching for enriched pathways in the mtDEG lists. In addition, induced network modules (default settings) were analysed for the gene lists obtained by short time series expression miner (STEM) analysis as described below.

\section{STEM analysis}

STEM (version 1.3.8) (Ernst \& Bar-Joseph, 2006) was used for the assessment of MMP $\downarrow$-related DEGs (see Results section) that were similarly deregulated over time. Settings were based on previous publications (Deferme et al., 2013). Expression profiles and gene lists were generated for each exposure condition separately (i.e. ASB2, CNT025, CNT2), and overlapping genes present in common expression profiles of at least two of the three exposure conditions were listed for further analysis. Gene sets showing similar expression profiles over time were analysed for enrichment of pathways and induced network modules in CPDB as described above.

\section{DTW4Omics analysis}

Dynamic time warping specifically designed for time series omics data (DTW4Omics) (Cavill et al., 2013) was used to anti-correlate DEGs and DEmiRs over time. The method considers time shifts between data sets and identifies negative correlations, even if changes happen at different time points. DTW4omics was used in endpoint mode, meaning every DEG was compared with every DEmiR within each exposure condition. In order to match 
negative correlations, both data sets were unit-variance scaled (to overcome differences in magnitude between the measurements). DEmiR values were multiplied by -1 , to allow anticorrelations to be detected. DTW4Omics uses permutations to estimate the probability of matches occurring by chance. DEGDEmiR pairs with significantly similar opposite time courses were identified for each exposure condition.

\section{Results}

\section{Changes in mitochondrial membrane potential and superoxide radical formation}

At $24 \mathrm{~h}$, MWCNTs caused a significant mitochondrial depolarisation at all tested doses $\left(0.25,2\right.$ and $\left.10 \mu \mathrm{g} / \mathrm{cm}^{2}\right)$ in a dosedependent manner (Figure 1A). Asbestos caused a significant depolarisation at the two higher doses $\left(2\right.$ and $\left.10 \mu \mathrm{g} / \mathrm{cm}^{2}\right)$, but not at the lowest dose. Glass wool did not cause a statistically significant depolarisation at any of the doses. The positive control CCCP induced a strong depolarisation of mitochondria in almost $100 \%$ of the cells.

At $48 \mathrm{~h}$, none of the materials induced a significant MMP $\downarrow$ at the lowest dose $\left(0.25 \mu \mathrm{g} / \mathrm{cm}^{2}\right)$, while MWCNT2 and ASB2 showed persistent MMP $\downarrow$ after the 48-h exposure (Figure S1). GW did not induce any change in MMP at $48 \mathrm{~h}$, while the positive control, CCCP, persistently decreased MMP in almost all cells.

No significant changes in mitochondrial radical formation were detected for any of the materials (data not shown).

\section{Differentially expressed genes and miRNAs}

DEGs and DEmiRs were identified for each exposure condition, and the union of DEGs/DEmiRs, i.e. the genes/miRNAs that were significantly deregulated in at least one time point, was used for further analysis of each exposure type (ASB025, ASB2, MWCNT025, MWCNT2, GW025 and GW2). Nuclear-transcribed mitochondria-related genes and miRNAs (mtDEGs/ mitomiRs; see Materials and Methods section) were identified from each list.

In general, a dose-related increase in number of DEGs was observed for MWCNTs and GW, while a dose-related decrease could be observed for ASB (Figure S2). In contrast, mtDEGs showed a dose-related increase for MWCNTs and ASB, while GW showed a slight dose-related decrease in percentage of mtDEGs (Figure S2).

For DEmiRs, a dose-related increase was observed for MWCNTs and ASB, while a dose-related decrease was seen for GW (Figure S2). In addition, mitomiRs (see Materials \& Methods section) showed a dose-related decrease for all materials (Figure S2).

\section{DEGs and mtDEGs related to MMP}

The total numbers of DEGs in ASB2, MWCNT2 and MWCNT025 (exposure conditions inducing MMP $\downarrow$ ) were compared, and 330 genes were found in common and thus considered to be a signature of MMP $\downarrow$ (Figure 1B). Twenty-six mtDEGs were identified in the MMP $\downarrow$-associated signature (Table 2). Similarly, the total numbers of DEGs between ASB025, GW025 and GW2 (samples with unchanged MMP) were compared, and 333 genes were found in common (Figure S3). This gene list served as a control list representing unchanged MMP. Nineteen mtDEGs were identified in the unchanged MMP signature (Table 2). The MMP-associated DEGs are available in Table S1.

\section{Similarity between the exposure conditions over time}

To elucidate the effect of the MMP-related DEGs over time, the two gene lists were combined to generate a list of 558 unique
DEGs, which were used to produce PCA plots based on the Euclidean distances calculated for each time point separately.

ASB2, MWCNT025 and MWCNT2 exposures inducing MMP $\downarrow$ showed similarity over time at most time points (indicated by red circles in Figure S4), especially at $6 \mathrm{~h}$.

\section{GO terms and pathways related to MMP}

The two MMP-related lists were analysed for enrichment of GO terms. Decreased and unchanged MMP were found to be related to 102 and 73 GO terms, respectively (including biological processes, molecular functions, and cellular components; Table S2). Only 11 GO terms were common to both decreased and unchanged MMP. Biological processes and cellular components related to mitochondrial function, such as gluconeogenesis, intrinsic apoptotic signalling (both in response to p53 and endoplasmic reticulum stress), fatty acid oxidation, and mitochondrial membrane were prominent among the MMP $\downarrow$-associated GO terms. In contrast, the GO terms associated with unchanged MMP were mainly related to DNA- and RNAmodifying processes, such as transcription, but also biosynthetic and metabolic processes (Table S2).

Six biological pathways and four GO terms strongly associated with mitochondrial function were enriched among the $26 \mathrm{MMP} \downarrow$ associated mtDEGs (Table 2; Figure 1C). The 19 mtDEGs associated with unchanged MMP showed enrichment of only one biological pathway (Table 2).

\section{Temporal expression profile analysis}

The MMP $\downarrow$-associated genes were analysed to identify sets of genes showing similar expression profiles over time for each exposure condition. Ten profiles each were identified for CNT025 and CNT2, and eight profiles for ASB2. Seven profiles were common among all three exposure conditions (Figure 1D, Figure S5), and within those profiles a total of 109 genes were common to at least two of the three conditions (Table S3). The most significant profile (Profile 1; Figure 1D) showed the highest number of common genes (49) with highly similar expression profiles over time (Table S3). These genes were involved in 19 pathways and GO terms, including several mitochondria-related ones such as mitochondrial LC-fatty acid $\beta$-oxidation and the mitochondrial matrix (data not shown). In addition, genes related to spindle microtubule function, such as $K I F 3 A$ (kinesin family member $3 \mathrm{~A}$ ) and $S K A 1$ (spindle and kinetochore associated complex subunit 1) were enriched. Furthermore, a large part of the 49 genes were found to form an interaction network including two central mitochondria-related transcription factors; NRF1 (nuclear respiratory factor 1) and APP (amyloid beta [A4] precursor protein) (Figure 1E).

\section{DEmiRs related to MMP}

Four MMP $\downarrow$-correlated miRNAs were identified by comparing the DEmiRs in the exposure conditions inducing MMP $\downarrow$ (i.e. ASB2, CNT2 and CNT025) (Table 2, Figure 1F). The expression profiles of each miRNA were compared among the exposure conditions (Figure S6), and particularly miR-1275 showed highly similar profiles in all three exposure conditions (Figure 1G). Five miRNAs were found in common between the experimental conditions, serving as controls for unchanged MMP (i.e. ASB025, GW025 and GW2; Table 2, Figure S3), but none of them showed highly similar expression profiles among the three exposure conditions (data not shown).

\section{Anti-correlation between DEGs and DEmiRs}

DTW4omics (Cavill et al., 2013) was used to analyse negative correlation between DEGs and the DEmiRs over time. 


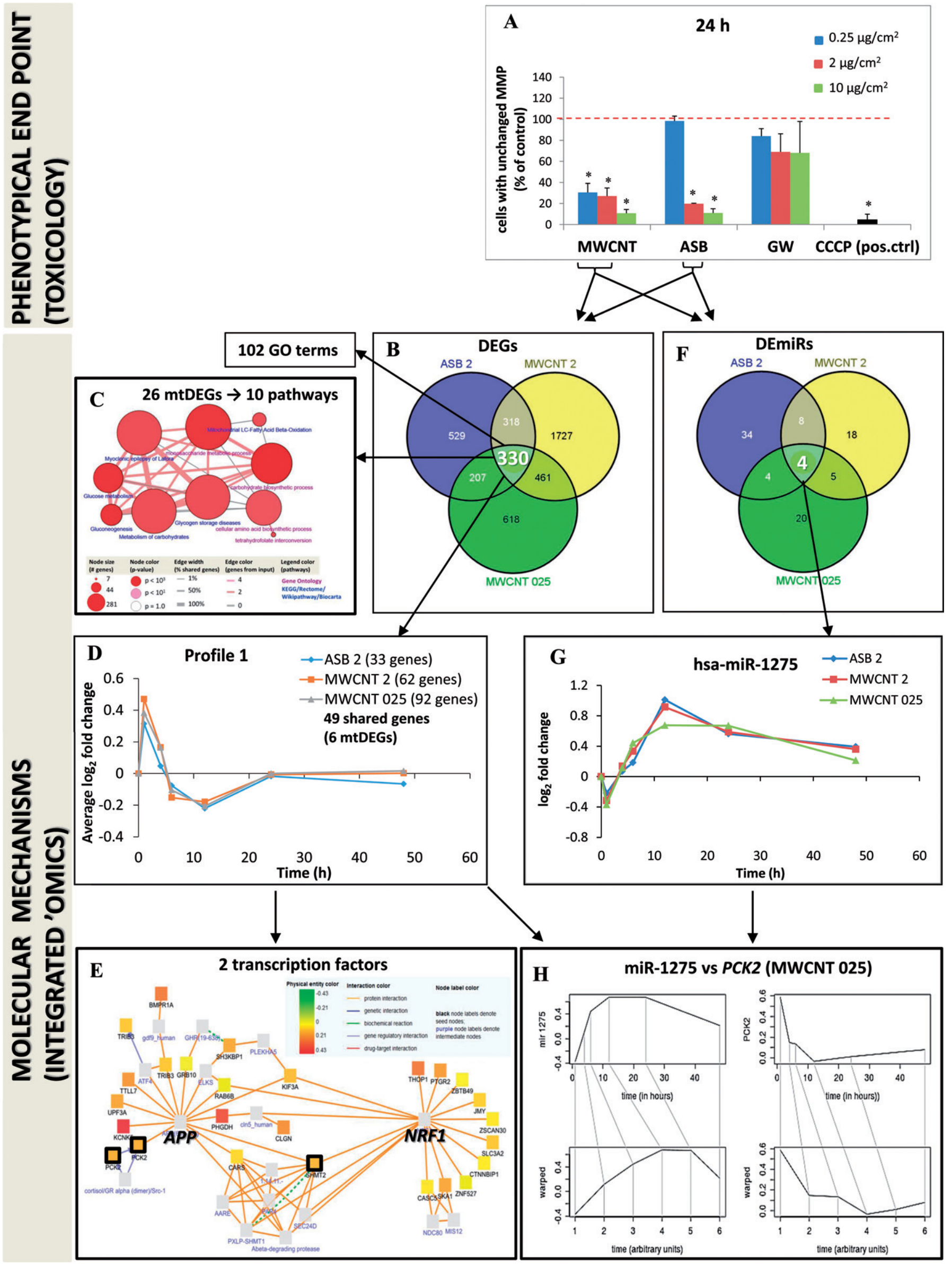


The union of DEGs from all time points was correlated with the union of DEmiRs from all time points for each exposure condition (i.e. regardless of the MMP status of the sample). Altogether, 51 of the $330 \mathrm{MMP} \downarrow$-associated DEGs anti-correlated with at least one of the four miRNAs in all three exposure conditions (Table 3). In total, eight MMP $\downarrow$-associated mtDEGs (ACADS, ADCK2, SHMT2, EHHADH, MSRB1, PCK2, SLC25A12 and $P C$ ) were found to anti-correlate with at least one miRNA (Table 3). In particular, miR-1275 showed prominent anticorrelation with large sets of DEGs in each of the three exposure conditions inducing MMP $\downarrow$. The large sets of DEGs showed significant enrichment of pathways involved in gluconeogenesis, mitochondrial membrane permeability and carbohydrate biosynthesis (data not shown). Interestingly, several of those DEGs were involved in expression profile 1 from the STEM analysis (Figure 1D; Table 3). For example, PCK2 anti-correlated with miR-1275 in CNT025 and CNT2 (Figure 1H and Figure S7), while ACADS anti-correlated with miR-1225-5p in ASB2 and with miR-1275 in CNT025 (Figure S7). In addition, miR-1275 anti-correlated with $P C$ and EHHADH in CNT2 and CNT025. Other examples included the predicted miR-1275 targets, the glucosidase gene $G A N A B$, which anti-correlated with miR-1275 in ASB2 (Figure S7) and the fatty acid elongase, ELOVL1, which anti-correlated with miR-1275 in CNT2. The complete lists of DEG-DEmiR anti-correlations can be found in Table S4.

Pearson correlation was also performed on the same data, to detect direct negative correlations without time shifts, but no significant results were obtained.

\section{Discussion}

This study showed that MWCNTs are capable of depolarising the mitochondrial membrane at lower doses than asbestos, while glass wool had no significant effect on MMP at any of the tested doses or time points. Asbestos-induced MMP $\downarrow$ has previously been associated with activation of the intrinsic apoptotic pathway, in part due to iron-derived ROS (Panduri et al., 2003). However, MWCNT-7 contains only small traces of iron and thus, decreases in MMP by this type of MWCNT are more likely due to intracellular ROS or potentially to a local iron-overload unrelated to the contamination of the fibres (Toyokuni, 2013). On the other hand, long-rigid MWCNTs, including MWCNT-7, have been found to generate a unique radical, which correlates with cytotoxicity and could potentially play a role in the effects on MMP (Nymark et al., 2014). In addition, the fibre dimensions may also explain the MMP $\downarrow$ according to the structure:activity paradigm whereby the high aspect ratio (HAR) and biopersistance is related to the toxic effects of fibres (Donaldson et al., 2010).
Table 2. Mitochondria-related differentially expressed genes (mtDEGs) and microRNAs (DEmiRs) associated with mitochondrial membrane potential (MMP). The complete list of MMP-associated DEGs can be found in Table S1.

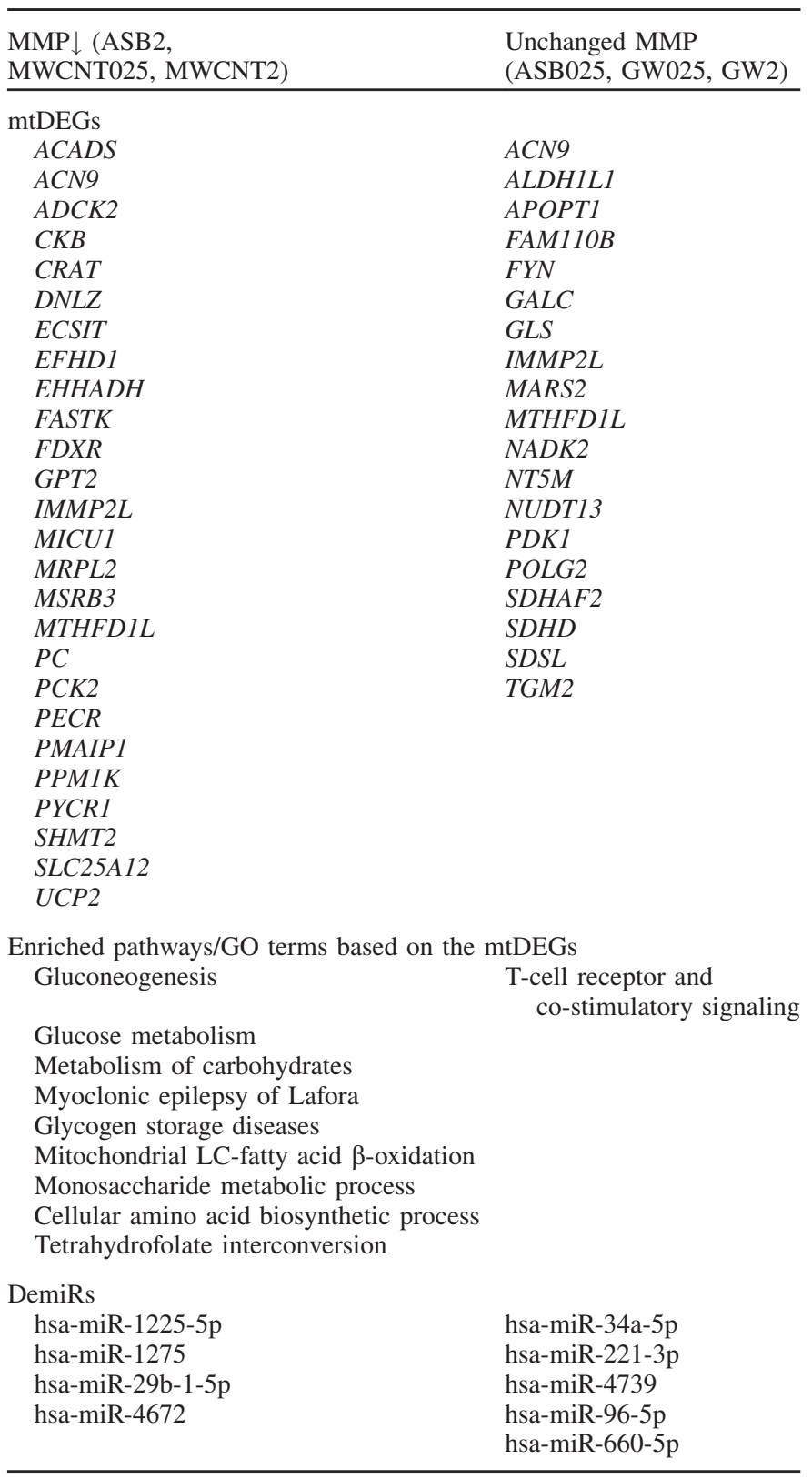

Figure 1. Schematic figure of the bioinformatics analysis approach and the results. (A) Changes in mitochondrial membrane potential (MMP) after a 24-h exposure to multi-walled carbon nanotubes (MWCNTs), asbestos (ASB) and glass wool (GW). Columns represent mean percentages of cells with unchanged MMP as compared with the control. The dashed line represents the normal control level. $* p<0.05$ for the difference between exposed cells and controls. (B) Overlap of differentially expressed genes (DEGs) between exposure conditions inducing decreased MMP (MMP $\downarrow$ ). The 330 common genes were used for further analysis as an MMP $\downarrow$-associated gene signature (Table S1). The signature showed enrichment of 102 GO terms (Table S2). (C) Twenty-six mitochondrial differentially expressed genes (mtDEGs) among the $330 \mathrm{MMP} \downarrow$-signature genes showed enrichment of 10 biological pathways and GO terms involved in mitochondrial functions (Table 2). (D) Expression profile of the most significant gene set among the 330 MMP $\downarrow$ associated DEGs. The other six profiles can be found in Supplementary material, and the complete lists of genes in each profile and for each exposure condition are listed in Table S3. (E) Molecular interaction network for the common genes in expression Profile 1 (49 genes common to at least 2/3 exposure conditions; Table S3). The regulation of the genes is represented by the expression at the 4-h time point (in the colored version available online, red - up-regulation; green - down-regulation). Genes in black squares indicate known mitochondria-related genes. (F) Overlap of DEmiRs between exposure conditions inducing MMP $\downarrow$. The 4 common miRNAs were used for further analysis as an MMP $\downarrow$-associated miRNA signature (Table 2). (G) Expression profile of one of the MMP $\downarrow$-associated miRNAs, miR-1275. Note the opposite regulation in comparison with the genes in Profile 1 (D). The expression profiles of the other three microRNAs can be found in Supplementary material. (H) Representative figure of anti-correlation between miR-1275 and PCK2 (one of the genes in Profile 1) in exposure condition MWCNT025. The upper two graphs are the original expression profiles of the miRNA and the gene, respectively. The lower two graphs represent the warped expression profiles generated by the DTW4omics method, and the lines between the plots show how the points map from one to the other including the time shifts. Other representative figures of DEGDEmiR anti-correlation pairs can be found in Supplementary material and the complete lists of DEG-DEmiR pairs can be found in Table S4. 
Table 3. MMP $\downarrow$-associated DEmiRs and the number of DEGs/mtDEGs showing anti-correlation over time.

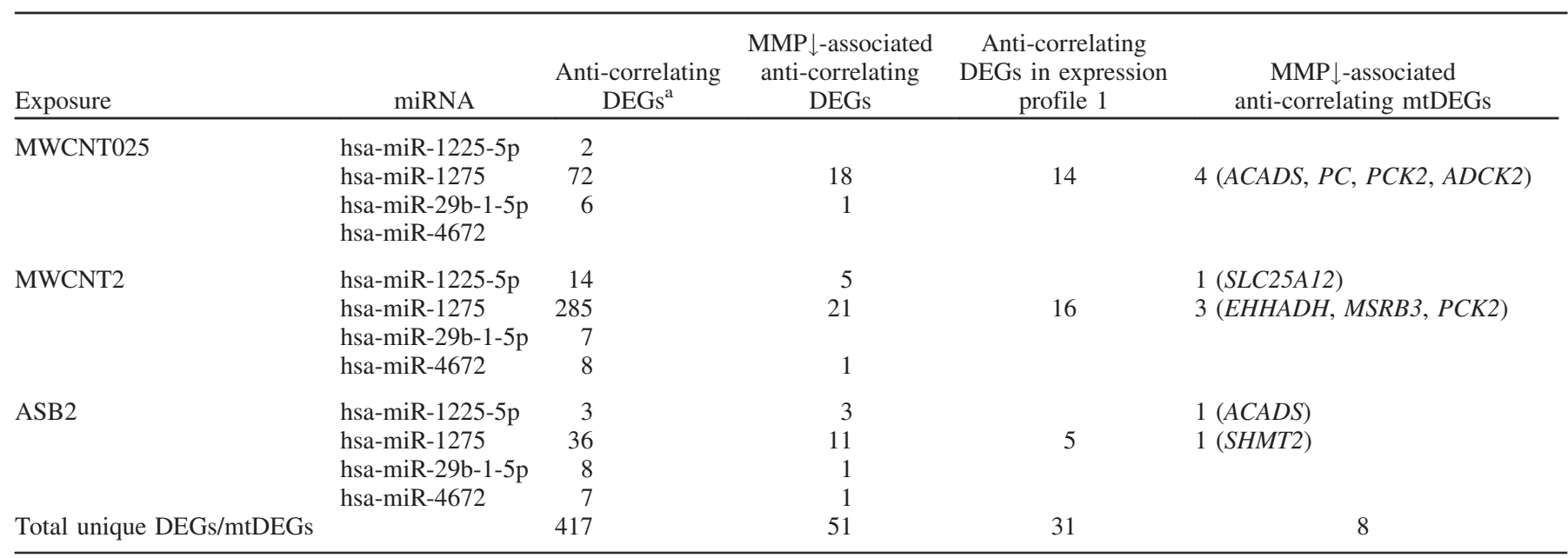

${ }^{\mathrm{a}}$ All anti-correlating DEGs, regardless of MMP $\downarrow$-association.

MWCNTs and crocidolite asbestos are highly biopersistant, while glass wool generally dissolves over time, possibly explaining why glass wool did not affect the MMP. On the other hand, long HAR glass fibres have been shown to remain after in vitro incubation (Osmond-Mcleod et al., 2011).

The phenotypical end point, MMP $\downarrow$, was further used to identify mechanistic associations through extensive profiling of the transcriptome and the miRNome in exposed cells over time. Overall the screening showed that the percentage of dysregulated nuclear-transcribed mitochondria-related genes increased with the dose of MWCNT and asbestos exposure, while the percentage of dysregulated mitomiRs decreased, pointing towards mitochondria-related gene-miRNA interactions induced by these two materials. In contrast, both mitochondria-related genes and mitomiRs decreased with the dose of glass wool and much fewer mitomiRs were identified than for the other materials.

\section{Genes and gene ontologies}

A signature of 330 genes that correlated with MWCNT- and asbestos-induced MMP $\downarrow$ was identified and used as a basis for the mechanistic analysis of both the 26 mitochondria-related genes included in the signature and the other genes with previously unknown involvement in mitochondrial function. The analysis approach as well as the results can be followed in Figure $1(\mathrm{~A}-\mathrm{H})$. The most significantly enriched biological process among these genes was the mitochondrial process gluconeogenesis. Gluconeogenesis partly takes place in the mitochondria, where it produces glucose from non-carbohydrate substrates such as pyruvate, lactate, glucogenic amino acids and fatty acids. This indicates that the signature indeed reflected mitochondrial dysfunction, even though it is possible that some of the genes in the signature are merely correlative with no direct relation to MMP $\downarrow$. Gluconeogenesis was also, together with other glucose metabolic pathways and mitochondrial fatty acid $\beta$-oxidation, identified among the 26 mitochondria-related genes in the MMP $\downarrow$-associated signature. Two of the genes involved in this process, the gluconeogenetic enzymes pyruvate carboxylase $(P C)$ and phosphoenolpyruvate carboxykinase ( $P C K 2)$, have previously been related to changes in MMP in rat liver cells (Ramzan et al., 2010). Gluconeogenesis is up-regulated during glucose deprivation, and $P C K 2$ has been shown to mediate an adaptive response to glucose deficiency in lung cancer (Leithner et al., 2014). Notably, $P C K 2$ is situated at the chromosomal region $14 \mathrm{q} 11.2$, in which DNA copy number changes have been associated with asbestos-related lung cancer (Nymark et al., 2006). Mitochondrial fatty acid $\beta$-oxidation, on the other hand, has been related to ROSmediated p53 induction (Assaily et al., 2011), and asbestos is known to activate p53 through several mechanisms, including phosphorylation, stabilisation and increased expression (Liu et al., 2013; Nymark et al., 2007).

Other enriched pathways among the $330 \mathrm{MMP} \downarrow$-correlated genes included intrinsic apoptotic signalling through both $\mathrm{p} 53$ mediators and in response to endoplasmic reticulum (ER) stress, as well as protein folding and misfolded protein binding. MMP $\downarrow$ has traditionally been associated with induction of the intrinsic (mitochondrial) apoptotic pathway, while accumulation of unfolded proteins and consequently ER stress leads to changes in calcium ion $\left(\mathrm{Ca}^{2+}\right)$ homeostasis, which is strongly related to the maintenance of MMP (Giorgi et al., 2012). Apoptosis-associated proteins were recently shown to be activated by MWCNT-7 in human macrophages (Palomäki et al., 2015). Furthermore, ER stress response has been suggested to be potentially useful as a sensitive and early-end point marker of nanotoxicity in a study on zinc oxide nanoparticles (Chen et al., 2014). There are also several lines of evidence that asbestos can induce ER stress and that this is related to both fibrosis (asbestosis) and epithelial-mesenchymal transition (EMT) (Liu et al., 2013). Fibrosis has also been identified in several in vivo MWCNT studies, many using specifically MWCNT-7 and other MWCNTs with similar properties, such as the long and rigid NM-401 (Murphy et al., 2011; Poulsen et al., 2013, 2015; Ryman-Rasmussen et al., 2009). NM401 has similar dimensions, metal impurities and redox/free radical generation capabilities as MWCNT-7 (Nymark et al., 2014).

\section{Transcription factors}

A significant number of the MMP $\downarrow$-associated genes (49/330) were found to have highly similar expression profiles over time following exposure to both MWCNTs and asbestos. Interestingly, many of the genes were found to be targets of two mitochondria-related transcription factors, namely NRF1 (nuclear respiratory factor 1) and $A P P$ (amyloid beta (A4) precursor protein). NRF1 controls several nuclear genes involved in respiration, heme biosynthesis, and mitochondrial DNA transcription/replication, while $A P P$ has been coupled to apoptosisinducing pathways. NRF1 inactivation has been linked to TGF $\beta 1$ over-expression, via a PGC-1 $\alpha(P P A R G C 1 A)$ pathway, in asbestos-exposed lung cancer cells (A549) (Pociask et al., 2004; Sohn et al., 2012). TGF $\beta 1$ is a mediator of both tissue fibrosis and 
tumour progression and is strongly associated with asbestos exposure (Nymark et al., 2008; Sohn et al., 2012). Notably, PPARGC1A was also associated with MMP $\downarrow$ induced by MWCNTs and asbestos in this study, and TGF $\beta 1$ was deregulated by $2 \mu \mathrm{g} / \mathrm{cm}^{2}$ MWCNTs and asbestos (data not shown).

\section{microRNAs}

Four miRNAs were found to correlate with MMP $\downarrow$ and all of them showed anti-correlation with several MMP $\downarrow$-associated genes. In particular, miR-1275 showed a prominent anti-correlation with several genes central in the processes mentioned above, indicating that miR-1275 could be a key regulator of these mitochondrial pathways. miR-1275 has not so far been studied very closely and target genes have not been verified. Nevertheless, the predicted targets (miRanda) include the MMP $\downarrow$-associated gene glucosidase $(G A N A B)$ and fatty acid elongase (ELOVL1), which anticorrelated with the miRNA after exposure to $2 \mu \mathrm{g} / \mathrm{cm}^{2}$ of MWCNTs. Other genes that show anti-correlation with a miRNA, but are not predicted to be targets of that specific miRNA, may nevertheless be regulated indirectly through other unknown mediator genes/molecules. Inhibition of miR-1275 has been associated with suppressed tumour cell proliferation in glioblastoma (Katsushima et al., 2012). Furthermore, miR-1225-
$5 \mathrm{p}$ may also play a role in this network of MMP $\downarrow$-associated genes and miRNAs since it anti-correlated with some of the genes (e.g. $A C A D S$ ) involved in mitochondrial LC-fatty acid $\beta$-oxidation.

Finally, it is worth mentioning that the mitotic spindle- and microtubule-related genes $K I F 3 A$ and $S K A 1$ also anti-correlated with miR-1275 in the MWCNT-exposed cells. MWCNTs have previously been shown to disrupt the mitotic spindle by integrating with the cellular microtubules (Siegrist et al., 2014) and to induce micronuclei which can be formed through spindle disturbances (Cveticanin et al., 2010; Di Giorgio et al., 2011; Muller et al., 2008). KIF3A and SKAl contributed to the enrichment of the molecular function "plus-end-directed microtubule motor activity" among the genes in the MMP $\downarrow$-associated signature and both genes were also found to be regulated by the transcription factors $A P P$ and $N R F 1$, described above, indicating that microtubule-related disturbances may in some way be related to mitochondrial dysfunctions. Indeed, microtubule-dependent activation of the NLRP3-inflammasome through aberrant mitochondrial homeostasis was recently demonstrated in vitro (Misawa et al., 2013). Notably, MWCNT-7 has been shown to activate the NLRP3-inflammasome in human primary macrophages in a similar manner as asbestos (Palomäki et al., 2011).
IIII Poulsen 2013 and 2015

V. Poulsen 2015 and Snyder-Talkington 2013

Poulsen 2013/2015 and Snyder-Talkington 2013

E Current study and Poulsen 2013/2015

N All studies

Current study

$\Delta$ miRnAs

$\square$ Genes/proteins

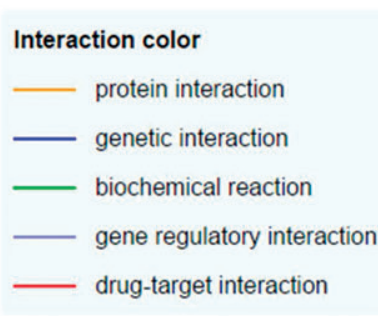

Node label color

black node labels denote seed nodes;

purple node labels denote intermediate nodes

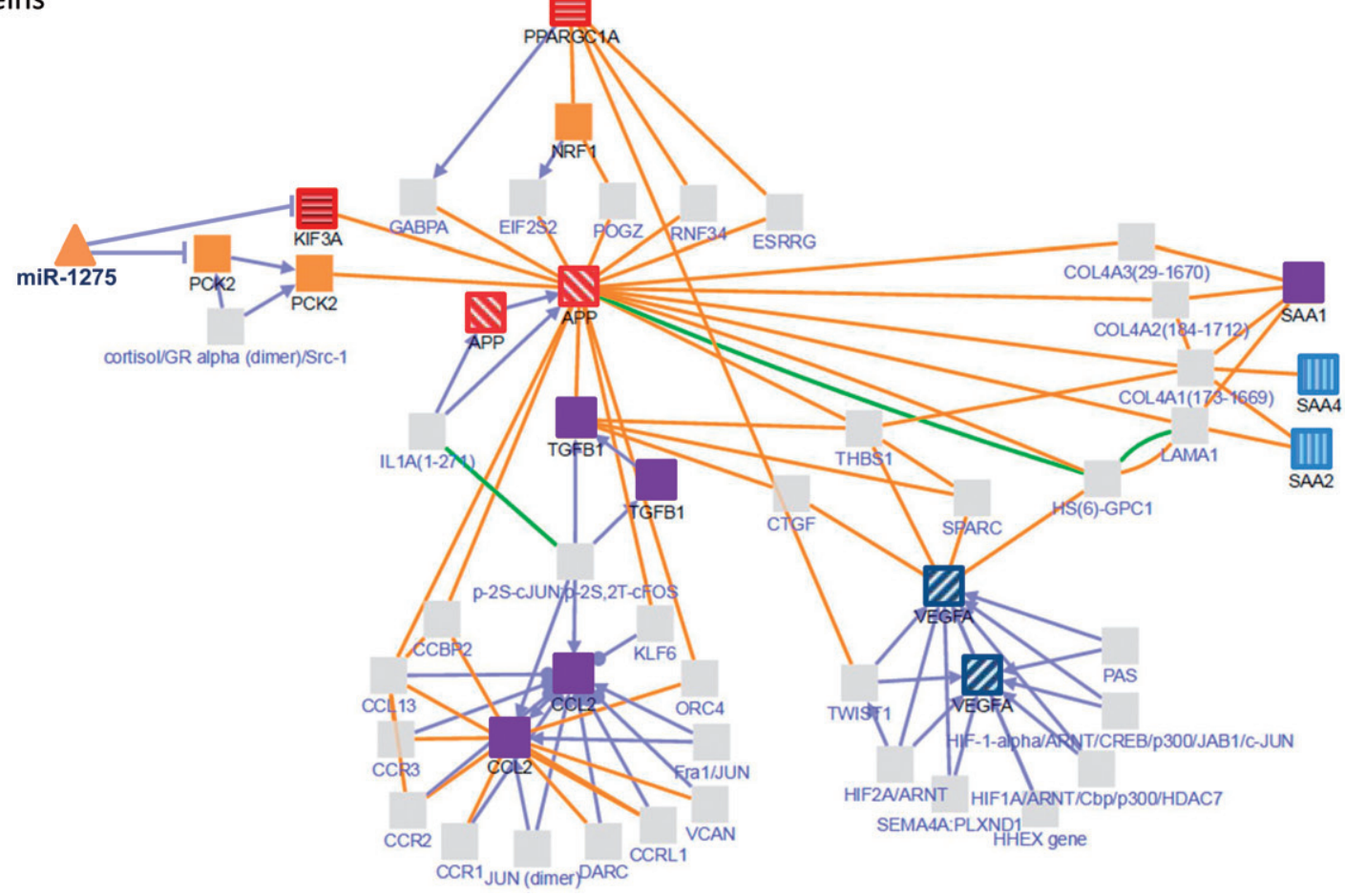

Figure 2. Interaction network of central genes identified in the current study or in three in vivo studies on MWCNTs. The genes used to produce the network (in CPDB) can be found in Table S5. Some gene names appear twice in the network, once for the node relating to the corresponding protein and once for the node relating to the gene itself. 


\section{Changes associated with the negative control}

In contrast to the results related to MMP $\downarrow$, the cells exposed to glass wool and to the low dose of asbestos, in which the MMP remained unchanged, showed deregulation of 333 genes involved in transcriptional, metabolic and biosynthetic processes; and five miRNAs, which exhibited no relevant anti-correlation with the 333 genes.

\section{Overlapping results with in vivo studies}

Interestingly, several of the genes mentioned above have been identified to various extents in three separate in vivo studies exposing mice to both MWCNT-7 and the similar NM-401 MWCNTs, as well as to the short NRCWE-26 MWCNTs (Poulsen et al., 2013, 2015; Snyder-Talkington et al., 2013). TGF $\beta 1$ was found to be deregulated in mice following intra-tracheal instillation or pharyngeal aspiration by both MWCNT-7 and NM-401, but not by short MWCNTs, while PPARGCIA, APP and KIF3A were deregulated by all types of MWCNT. Additionally, other highly central genes in the in vivo studies could be linked to the $A P P / N R F 1$ network, such as the highly up-regulated serum amyloid A protein genes $S A A 1, S A A 2$ and $S A A 4$ as well as the inflammation and fibrosis-associated genes, CCL2 and VEGFA. Amyloid proteins are strongly associated with Alzheimer's disease, which is largely linked to mitochondrial dysfunction, while VEGFA has been shown to be involved in mitochondrial biogenesis through PPARGC1A and NRF1 (Mao \& Reddy, 2011; Wright et al., 2008; Yamamoto et al., 2005). Notably, there are previous indications of altered Alzheimer's-related genes following MWCNT inhalation in mice (Sriram et al., 2009). The genes central to the current study and to the three in vivo studies mentioned above (Table S5) were found to form an interconnected regulatory network coupling mitochondrial dysfunctions in vitro to inflammation and fibrosis in vivo (Figure 2). The significance of these findings are further enhanced by the fact that the in vivo doses used in both Poulsen studies $\left(0.22 \mu \mathrm{g} / \mathrm{cm}^{2}\right.$ and $\left.1.98 \mu \mathrm{g} / \mathrm{cm}^{2}\right)$ correspond almost exactly to the in vitro doses $\left(0.25 \mu \mathrm{g} / \mathrm{cm}^{2}\right.$ and $2 \mu \mathrm{g} / \mathrm{cm}^{2}$ ) used here, indicating that these genes may provide relevant targets for further research, e.g. using gene silencing in vitro.

\section{Conclusions}

In conclusion, a set of 330 genes (including 26 known mitochondria-related genes, e.g. $P C K 2$ and $P C$ ), two transcription factors strongly involved in mitochondrial function (NRF1 and $A P P$ ) and four miRNAs (particularly miR-1275) were associated with the induction of decreased MMP following low-dose exposure to MWCNTs and asbestos. These genes and miRNAs were identified to contribute to deregulation of several mitochondrial processes such as glucose metabolism, gluconeogenesis, and mitochondrial LC-fatty acid $\beta$-oxidation, but also other processes such as microtubule-related functions. Some of the most central genes described here were also identified in three in vivo studies and are visualised in Figure 2. These overlapping findings link MWCNT-associated mitochondrial dysfunction in cells with MWCNT-induced inflammation and fibrosis in mice. Glass wool did not affect MMP and showed deregulation of entirely different pathways.

MMP $\downarrow$ was recently pointed out as a relevant initial step in exposure-related toxicity, and a significant effort was put into screening a large group of chemicals from the Tox 21 compound library (curated by the US Environmental Protection Agency) for changes in MMP using a high-throughput screening approach (Attene-Ramos et al., 2014). Structural-based clustering of the MMP-disrupting compounds identified molecular features of the chemicals that could be assumed to play a role in the observed activity. Although chemical compounds are structurally and molecularly very different from ENMs, similar mechanisms of action could provide basis for the development of clustering models for ENMs. Grouping of ENMs, as well as detailed knowledge on the mechanisms of action giving insight into the modes of action, is essential for twenty-first century risk assessment (Krewski et al., 2010). This study provides insight into the MMP $\downarrow$-associated molecular mechanisms underlying the toxicity of a well-studied type of MWCNT (MWCNT-7) and links the mechanisms to effects seen in vivo. These findings could provide a basis for developing screening methods based on MMPrelated changes.

\section{Acknowledgements}

We would like to thank Dr David Brown at the School of Life Sciences of the Heriot-Watt University (Edinburgh, United Kingdom) for providing us with glass wool (MMVF10) and Dr Pekka Kohonen for fruitful discussions.

\section{Declaration of interest}

The authors declare no conflicts of interests. This study was funded by the Marie Curie Intra-European Fellowship FP7299525 (miRNAno; P. N.), the Finnish Work Environment Fund (grant No. 112168; PN) and the Association for Promotion of Occupational Health in Finland (P. N.).

\section{References}

Antico Arciuch VG, Elguero ME, Poderoso JJ, Carreras MC. 2012. Mitochondrial regulation of cell cycle and proliferation. Antioxid Redox Signal 16:1150-80.

Assaily W, Rubinger D, Wheaton K, Lin Y, Ma W, Xuan W, et al. 2011. Ros-mediated p53 induction of lpin1 regulates fatty acid oxidation in response to nutritional stress. Mol Cell 44:491-501.

Attene-Ramos M, Huang R, Michael S, Witt K, Richard A, Tice R, et al. 2014. Profiling of the tox 21 chemical collection for mitochondrial function to identify compounds that acutely decrease mitochondrial membrane potential. Environ Health Perspect 123:49-56.

Bienertova-Vasku J, Sana J, Slaby O. 2013. The role of micrornas in mitochondria in cancer. Cancer Lett 336:1-7.

Cavill R, Kleinjans J, Briedé J-J. 2013. Dtw4omics: comparing patterns in biological time series. PLoS ONE 8:e71823.

Chen R, Huo L, Shi X, Bai R, Zhang Z, Zhao Y, et al. 2014. Endoplasmic reticulum stress induced by zinc oxide nanoparticles is an earlier biomarker for nanotoxicological evaluation. ACS Nano 8:2562-74.

Courcot E, Leclerc J, Lafitte J-J, Mensier E, Jaillard S, Gosset P, et al. 2012. Xenobiotic metabolism and disposition in human lung cell models: comparison with in vivo expression profiles. Drug Metab Dispos 40:1953-65.

Cveticanin J, Joksic G, Leskovac A, Petrovic S, Sobot A, Neskovic O. 2010. Using carbon nanotubes to induce micronuclei and double strand breaks of the DNA in human cells. Nanotechnology 21:015102.

Dai M, Wang P, Boyd AD, Kostov G, Athey B, Jones EG, et al. 2005. Evolving gene/transcript definitions significantly alter the interpretation of genechip data. Nucl Acid Res 33:e175.

De Volder MFL, Tawfick SH, Baughman RH, Hart AJ. 2013. Carbon nanotubes: present and future commercial applications. Science 339: 535-9.

Deferme L, Briedé JJ, Claessen SMH, Jennen DGJ, Cavill R, Kleinjans JCS. 2013. Time series analysis of oxidative stress response patterns in hepg2: a toxicogenomics approach. Toxicology 306:24-34.

Di Giorgio ML, Bucchianico SD, Ragnelli AM, Aimola P, Santucci S, Poma A. 2011. Effects of single and multi walled carbon nanotubes on macrophages: cyto and genotoxicity and electron microscopy. Mutat Res Genet Toxicol Environ Mutagen 722:20-31.

Donaldson K, Murphy F, Duffin R, Poland C. 2010. Asbestos, carbon nanotubes and the pleural mesothelium: a review of the hypothesis regarding the role of long fibre retention in the parietal pleura, inflammation and mesothelioma. Part Fibre Toxicol 7:5. 
Dörger M, Münzing S, Allmeling A, Krombach F. 2000. Comparison of the phagocytic response of rat and hamster alveolar macrophages to man-made vitreous fibers in vitro. Hum Exp Toxicol 19:635-40.

Eijssen LMT, Jaillard M, Adriaens ME, Gaj S, De Groot PJ, Müller M, Evelo CT. 2013. User-friendly solutions for microarray quality control and pre-processing on arrayanalysis.Org. Nucl Acid Res 41:W71-6.

Ernst J, Bar-Joseph Z. 2006. Stem: a tool for the analysis of short time series gene expression data. BMC Bioinformat 7:191.

Garcia-Canton C, Minet E, Anadon A, Meredith C. 2013. Metabolic characterization of cell systems used in in vitro toxicology testing: lung cell system beas-2b as a working example. Toxicol Vitro 27:1719-27.

Geiser M, Matter M, Maye I, Im Hof V, Gehr P, Schürch S. 2003. Influence of airspace geometry and surfactant on the retention of manmade vitreous fibers (mmvf 10a). Environ Health Perspect 111: 895-901.

Gilmour PS, Brown DM, Beswick PH, Macnee W, Rahman I, Donaldson K. 1997. Free radical activity of industrial fibers: role of iron in oxidative stress and activation of transcription factors. Environ Health Perspect 105:1313-17.

Giorgi C, Agnoletto C, Bononi A, Bonora M, De Marchi E, Marchi S, et al. 2012. Mitochondrial calcium homeostasis as potential target for mitochondrial medicine. Mitochondrion 12:77-85.

Grosse Y, Loomis D, Guyton KZ, Lauby-Secretan B, El Ghissassi F, Bouvard V, et al. 2014. Carcinogenicity of fluoro-edenite, silicon carbide fibres and whiskers, and carbon nanotubes. Lancet Oncol 15: 1427-8.

Haniu H, Saito N, Matsuda Y, Kim Y-A, Park K, Tsukahara T, et al. 2011. Elucidation mechanism of different biological responses to multiwalled carbon nanotubes using four cell lines. Int $\mathrm{J}$ Nanomed. 6: 3487-97.

Hebels D Ga J, Briedé JJ, Khampang R, Kleinjans JCS, De Kok TMCM. 2010. Radical mechanisms in nitrosamine- and nitrosamide-induced whole-genome gene expression modulations in caco-2 cells. Toxicol Sci 116:194-205.

Hesterberg TW, Axten C, Mcconnell EE, Oberdörster G, Everitt J, Miiller WC, et al. 1997. Chronic inhalation study of fiber glass and amosite asbestos in hamsters: Twelve-month preliminary results. Environ Health Perspect 105:1223-9.

Hesterberg TW, Miiller WC, Mcconnell EE, Chevalier J, Hadley JG, Bernstein DM, et al. 1993. Chronic inhalation toxicity of size-separated glass fibers in fischer 344 rats. Toxicol Sci 20:464-76.

Huang DW, Sherman BT, Lempicki RA. 2008. Systematic and integrative analysis of large gene lists using david bioinformatics resources. Nat Protocols 4:44-57.

Huang S, Partridge M, Ghandhi S, Davidson M, Amundson S, Hei T. 2012. Mitochondria-derived reactive intermediate species mediate asbestos-induced genotoxicity and oxidative stress-responsive signaling pathways. Environ Health Perspect 120:840-7.

IARC. 2002. Man-Made Vitreous Fibres. IARC Monographs. France: IARC.

Jensen CG, Watson M. 1999. Inhibition of cytokinesis by asbestos and synthetic fibres. Cell Biol Int 23:829-40.

Jensen KA. 2013. Deliverable 4.1: Summary report on primary physicochemical properties of manufactured nanomaterials used in NANOGENOTOX. Available at: http://www.nanogenotox.eu/files/ PDF/Deliverables/d4.1_summary\%20report.pdf. Accessed on 1st August 2014.

Kamburov A, Stelzl U, Lehrach H, Herwig R. 2013. The consensuspathdb interaction database: 2013 update. Nucl Acid Res 41:D793-800.

Katsushima K, Shinjo K, Natsume A, Ohka F, Fujii M, Osada H, et al. 2012. Contribution of microrna-1275 to claudin 11 protein suppression via a polycomb-mediated silencing mechanism in human glioma stemlike cells. J Biol Chem 287:27396-406.

Kinnula VL, Yankaskas JR, Chang L, Virtanen I, Linnala A, Kang BH, Crapo JD. 1994. Primary and immortalized (beas 2b) human bronchial epithelial cells have significant antioxidative capacity in vitro. Am J Resp Cell Mol Biol 11:568-76.

Krewski D, Acosta D, Andersen M, Anderson H, Bailar JC, Boekelheide $\mathrm{K}$, et al., Staff of Committee on Toxicity $\mathrm{T} \&$ Assessment of Environmental A. 2010. Toxicity testing in the 21st century: a vision and a strategy. J Toxicol Environ Health, Part B 13:51-138.

Leithner K, Hrzenjak A, Trotzmuller M, Moustafa T, Kofeler HC, Wohlkoenig C, et al. 2014. Pck2 activation mediates an adaptive response to glucose depletion in lung cancer. Oncogene 34:1044-50.

Lindberg HK, Falck GCM, Singh R, Suhonen S, Järventaus H, Vanhala E, et al. 2013. Genotoxicity of short single-wall and multi-wall carbon nanotubes in human bronchial epithelial and mesothelial cells in vitro. Toxicology 313:24-37.

Liu G, Cheresh P, Kamp DW. 2013. Molecular basis of asbestos-induced lung disease. Annu Rev Pathol: Mech Dis 8:161-87.

Liu G, Kamp DW. 2011. Mitochondrial DNA damage: role of ogg1 and aconitase. In: Kruman I, ed. DNA Repair. Rijeka, Croatia: InTech, 85-102.

Lopez-Romero P. 2011. Pre-processing and differential expression analysis of agilent microrna arrays using the agimicrorna bioconductor library. BMC Genom 12:64.

Mao P, Reddy PH. 2011. Aging and amyloid beta-induced oxidative DNA damage and mitochondrial dysfunction in alzheimer's disease: implications for early intervention and therapeutics. Biochim Biophys Acta 1812:1359-70.

Mcconnell E, Axten C, Hesterberg T, Chevalier J, Miiller W, Everitt J, et al. 1999. Studies on the inhalation toxicology of two fiberglasses and amosite asbestos in the syrian golden hamster. Part ii. Results of chronic exposure. Inhal Toxicol 11:785-835.

Misawa T, Takahama M, Kozaki T, Lee H, Zou J, Saitoh T, Akira S. 2013. Microtubule-driven spatial arrangement of mitochondria promotes activation of the nlrp3 inflammasome. Nat Immunol 14:454-60.

Mishra A, Rojanasakul Y, Chen BT, Castranova V, Mercer RR, Wang L. 2012. Assessment of pulmonary fibrogenic potential of multiwalled carbon nanotubes in human lung cells. J Nanomat 2012:930931.

Muller J, Decordier I, Hoet PH, Lombaert N, Thomassen L, Huaux F, et al. 2008. Clastogenic and aneugenic effects of multi-wall carbon nanotubes in epithelial cells. Carcinogenesis 29:427-33.

Murphy FA, Poland CA, Duffin R, Al-Jamal KT, Ali-Boucetta H, Nunes A, et al. 2011. Length-dependent retention of carbon nanotubes in the pleural space of mice initiates sustained inflammation and progressive fibrosis on the parietal pleura. Am J Pathol 178:2587-600.

Murray A, Kisin E, Tkach A, Yanamala N, Mercer R, Young S-H, et al. 2012. Factoring-in agglomeration of carbon nanotubes and nanofibers for better prediction of their toxicity versus asbestos. Part Fibre Toxicol 9:10.

Nabben M, Hoeks J, Moonen-Kornips E, Van Beurden D, Briedé JJ, Hesselink MKC, et al. 2011. Significance of uncoupling protein 3 in mitochondrial function upon mid- and long-term dietary high-fat exposure. FEBS Lett 585:4010-17.

Nymark P, Jensen K, Suhonen S, Kembouche Y, Vippola M, Kleinjans J, et al. 2014. Free radical scavenging and formation by multi-walled carbon nanotubes in cell free conditions and in human bronchial epithelial cells. Partic Fibre Toxicol 11:4.

Nymark P, Lindholm P, Korpela M, Lahti L, Ruosaari S, Kaski S, et al. 2007. Gene expression profiles in asbestos-exposed epithelial and mesothelial lung cell lines. BMC Genom 8:62.

Nymark P, Wikman H, Hienonen-Kempas T, Anttila S. 2008. Molecular and genetic changes in asbestos-related lung cancer. Cancer Lett 265: $1-15$.

Nymark P, Wikman H, Ruosaari S, Hollmén J, Vanhala E, Karjalainen A, et al. 2006. Identification of specific gene copy number changes in asbestos-related lung cancer. Cancer Res 66:5737-43.

Oliveros J. 2007. An interactive tool for comparing lists with venn diagrams. Available at: http://bioinfogp.Cnb.Csic.Es/tools/venny/ index.html. Accessed on 15th January 2015.

Osmond-Mcleod M, Poland C, Murphy F, Waddington L, Morris H, Hawkins S, et al. 2011. Durability and inflammogenic impact of carbon nanotubes compared with asbestos fibres. Part Fibre Toxicol 8:15.

Palomäki J, Sund J, Vippola M, Kinaret P, Greco D, Savolainen K, et al. 2015. A secretomics analysis reveals major differences in the macrophage responses towards different types of carbon nanotubes. Nanotoxicology [Epub ahead of print]: 1-10. doi: 10.3109/ 17435390.2014.969346.

Palomäki J, Välimäki E, Sund J, Vippola M, Clausen PA, Jensen KA, et al. 2011. Long, needle-like carbon nanotubes and asbestos activate the nlrp3 inflammasome through a similar mechanism. ACS Nano 5: 6861-70.

Panduri V, Weitzman SA, Chandel N, Kamp DW. 2003. The mitochondria-regulated death pathway mediates asbestos-induced alveolar epithelial cell apoptosis. Am J Resp Cell Mol Biol 28:241-8.

Panduri V, Weitzman SA, Chandel NS, Kamp DW. 2004. Mitochondrialderived free radicals mediate asbestos-induced alveolar epithelial cell apoptosis. Am J Physiol - Lung Cell Mol Physiol 286:L1220-7.

Piskernik C, Haindl S, Behling T, Gerald Z, Kehrer I, Redl H, Kozlov AV. 2008. Antimycin a and lipopolysaccharide cause the leakage of 
superoxide radicals from rat liver mitochondria. Biochim Biophys Acta - Molecular Basis of Disease 1782:280-5.

Pociask DA, Sime PJ, Brody AR. 2004. Asbestos-derived reactive oxygen species activate tgf-[beta]1. Lab Invest 84:1013-23.

Poland CA, Duffin R, Kinloch I, Maynard A, Wallace Wa H, Seaton A, et al. 2008. Carbon nanotubes introduced into the abdominal cavity of mice show asbestos-like pathogenicity in a pilot study. Nat Nano 3: 423-8.

Poulsen SS, Jacobsen NR, Labib S, Wu D, Husain M, Williams A, et al. 2013. Transcriptomic analysis reveals novel mechanistic insight into murine biological responses to multi-walled carbon nanotubes in lungs and cultured lung epithelial cells. PLoS ONE 8:e80452.

Poulsen SS, Saber AT, Williams A, Andersen O, Købler C, Atluri R, et al. 2015. MWCNTs of different physicochemical properties cause similar inflammatory responses, but differences in transcriptional and histological markers of fibrosis in mouse lungs. Toxicol Appl Pharmacol 284:16-32.

Prokisch H, Andreoli C, Ahting U, Heiss K, Ruepp A, Scharfe C, Meitinger T. 2006. Mitop2: the mitochondrial proteome databasenow including mouse data. Nucl Acid Res 34:D705-11.

Pulskamp K, Diabaté S, Krug HF. 2007. Carbon nanotubes show no sign of acute toxicity but induce intracellular reactive oxygen species in dependence on contaminants. Toxicol Lett 168:58-74.

R Core team. 2014. R: A Language and Environment for Statistical Computing. Vienna, Austria: R Foundation for Statistical Computing.

Ramzan R, Staniek K, Kadenbach B, Vogt S. 2010. Mitochondrial respiration and membrane potential are regulated by the allosteric atpinhibition of cytochrome $\mathrm{c}$ oxidase. Biochim Biophys Acta Bioenergetics 1797:1672-80.

Reddel RR, Ke Y, Gerwin BI, Mcmenamin MG, Lechner JF, Su RT, et al. 1988. Transformation of human bronchial epithelial cells by infection with sv40 or adenovirus-12 sv40 hybrid virus, or transfection via strontium phosphate coprecipitation with a plasmid containing sv40 early region genes. Cancer Res 48:1904-9.

Ryman-Rasmussen JP, Tewksbury EW, Moss OR, Cesta MF, Wong BA, Bonner JC. 2009. Inhaled multiwalled carbon nanotubes potentiate airway fibrosis in murine allergic asthma. Am J Resp Cell Mol Biol 40: 349-58.

Sargent L, Porter D, Staska L, Hubbs A, Lowry D, Battelli L, et al. 2014. Promotion of lung adenocarcinoma following inhalation exposure to multi-walled carbon nanotubes. Part Fibre Toxicol 11:3.

Searl A, Buchanan D, Cullen RT, Jones AD, Miller BG, Soutar CA. 1999. Biopersistence and durability of nine mineral fibre types in rat lungs over 12 months. Ann Occup Hyg 43:143-53.

Siegrist K, Reynolds S, Kashon M, Lowry D, Dong C, Hubbs A, et al. 2014. Genotoxicity of multi-walled carbon nanotubes at occupationally relevant doses. Part Fibre Toxicol 11:6.

Smyth GK, Michaud J, Scott HS. 2005. Use of within-array replicate spots for assessing differential expression in microarray experiments. Bioinformatics 21:2067-75.
Snyder-Talkington B, Dymacek J, Porter D, Wolfarth M, Mercer R, Pacurari M, et al. 2013. System-based identification of toxicity pathways associated with multi-walled carbon nanotube-induced pathological responses. Toxicol Appl Pharmacol 272:476-89.

Sohn EJ, Kim J, Hwang Y, Im S, Moon Y, Kang DM. 2012. Tgf-beta suppresses the expression of genes related to mitochondrial function in a549 cells. Cell Mol Biol (Noisy-le-grand) 58:OL1763-7.

Sriram K, Porter D, Jefferson A, Lin G, Wolfarth M, Chen B, et al. 2009. Neuroinflammation and blood-brain barrier changes following exposure to engineered nanomaterials. Toxicologist 108:458.

Takagi A, Hirose A, Futakuchi M, Tsuda H, Kanno J. 2012. Dosedependent mesothelioma induction by intraperitoneal administration of multi-wall carbon nanotubes in p53 heterozygous mice. Cancer Sci 103:1440-4.

Takagi A, Hirose A, Nishimura T, Fukumori N, Ogata A, Ohashi N, et al. 2008. Induction of mesothelioma in p53+/- mouse by intraperitoneal application of multi-wall carbon nanotube. J Toxicol Sci 33:105-16.

Tomasetti M, Neuzil J, Dong L. 2014. Micrornas as regulators of mitochondrial function: role in cancer suppression. Biochim Biophys Acta - General Subjects 1840:1441-53.

Topinka J, Loli P, Dušinská M, Hurbánková M, Kováčiková Z, Volkovová $\mathrm{K}$, et al. 2006. Mutagenesis by man-made mineral fibres in the lung of rats. Mutat Res Fundam Mol Mech Mutagen 595:174-83.

Toyokuni S. 2013. Genotoxicity and carcinogenicity risk of carbon nanotubes. Adv Drug Deliv Rev 65:2098-110.

Tran CL, Jones AD, Donaldson K. 1996. Evidence of overload, dissolution and breakage of mmvf10 fibres in the rec chronic inhalation study. Exp Toxicol Pathol 48:500-4.

Van Den Hof WFPM, Van Summeren A, Lommen A, Coonen MLJ, Brauers K, Van Herwijnen M, et al. 2014. Integrative cross-omics analysis in primary mouse hepatocytes unravels mechanisms of cyclosporin a-induced hepatotoxicity. Toxicology 324:18-26.

Wang L, Stueckle TA, Mishra A, Derk R, Meighan T, Castranova V, Rojanasakul Y. 2014. Neoplastic-like transformation effect of singlewalled and multi-walled carbon nanotubes compared to asbestos on human lung small airway epithelial cells. Nanotoxicology 8: $485-507$.

Wang X, Guo J, Chen T, Nie H, Wang H, Zang J, Cui X, Jia G. 2012. Multi-walled carbon nanotubes induce apoptosis via mitochondrial pathway and scavenger receptor. Toxicol Vitro 26:799-806.

Wright GL, Maroulakou IG, Eldridge J, Liby TL, Sridharan V, Tsichlis PN, Muise-Helmericks RC. 2008. Vegf stimulation of mitochondrial biogenesis: requirement of akt3 kinase. FASEB 22:3264-75.

Yamamoto M, Horiba M, Buescher JL, Huang D, Gendelman HE, Ransohoff RM, Ikezu T. 2005. Overexpression of monocyte chemotactic protein- $1 / \mathrm{ccl} 2$ in $\beta$-amyloid precursor protein transgenic mice show accelerated diffuse $\beta$-amyloid deposition. Am J Pathol 166: 1475-85. 